\title{
Modifying and Assessing Validity and Reliability of Motivation for Reading Questionnaire
}

\author{
Toni Indriayadi \\ Institut Agama Islam Negeri Kerinci \\ toniindrayadi2@gmail.com
}

\begin{abstract}
This study aimed to describe the modification process and validity and reliability assessment of instruments regarding motivations for the reading questionnaire (MRQ) for measuring reading motivation of junior high school students in Jambi, Indonesia. Eighty-three students participated in this study, selected through the respondent who returned the questionnaires. The corrected items' total correlation of SPSS 23 was applied to examine the validity and reliability of MRQ. The corrected items' total correlation of SPSS statistical analyses showed that all of the 53 modification items of MRQ were valid and reliable. It indicated that all 53 items of $M R Q$ were appropriate for measuring the reading motivation of junior high school students in Jambi, Indonesia. It can provide a future studies screening tool for measuring the students' reading motivation.
\end{abstract}

Keywords: Modifying and Assessing, Motivations for Reading Questionnaire, MRQ, V alidity and Reliability

\section{INTRODUCTION}

Motivated students tend to engage in learning activities that help them learn and achieve the learning goal because they pay attention and effectively use the time during class and learning (Jones, 2009). Reading motivation in EFL among students is commonly measurable using a questionnaire. Accurate measurement of reading motivation, therefore, needs the intervention of research. Self-reported questionnaires are often ineffective due to their practicality and ability to contextualize. However, the self-report questionnaire provides a more accurate reading motivation estimate but is difficult to administer to junior high school students with different characteristics.

Motivation in reading is considerably essential in reading engagement that affects on results of reading achievement. It relates to mental readiness, willingness, beliefs, and perception to engage in reading (Alhamdu, 2015). Motivation is fundamental in comprehending the text because it enables to create interest in reading. Interest in reading is a personal investment constructed through motivation (Guthrie, Coddington, \& Wigfield, 2009). It relates to the students' intrinsic motivation that refers to the inner tendency of an individual. Therefore, the students' motivation needs to be considered by teachers in teaching reading in the class.

In 2004, Wang and Guthrie modeled Wigfield and Guthrie 1997's motivations for reading questionnaire (MRQ) for measuring the reading motivation of Taiwan elementary school students. The participants of their study consisted of 187 US and 197 Chinese students. All of the students lived in Taipei, an urban environment, and were native Chinese speakers. The MRQ modification has successfully collected data on the Taiwan elementary school students' reading motivation (Wang \& Guthrie, 2004). However, MRQ reading has not been modified as a screening tool for measuring EFL's reading motivation like Indonesian students. Therefore, 
Wang and Guthrie 2004's motivations for the reading questionnaire are considered appropriate to be modified for measuring EFL reading motivation for junior high students in Indonesia.

MRQ of Wang \& Guthrie is the intersection of eight dimensions of reading motivation from two factors of the motivational model for reading; intrinsic and extrinsic motivation factors. The first is intrinsic motivation that comprises three dimensions; reading for curiosity, reading for involvement, and reading for the challenge. The second factor is an extrinsic motivation that comprises five dimensions; reading for recognition, reading for a grade, reading for social, reading for competition, and reading for compliance.

However, this questionnaire also needed to be translated into Indonesian and supported by face and content validity before being used for measuring junior high school student's reading motivation as stated by Stewart, Thrasher, Goldberg, and Shea (2012) that the researchers must translate a modified questionnaire for use in non-English speaking countries. The translation makes the items easily understood by the Indonesian junior high school student as the targeted participants before face validity and validity and reliability SPSS analysis. Assessing the validity and reliability of the study questionnaire is very important for providing the researcher with an understandable instrument. Therefore, the purpose of this study determines modifying Wang and Guthrie's MRQ as a screening tool for measuring Junior high school students' reading motivation in Indonesia.

This study firstly aimed to describe the modification process of motivations for reading questionnaire to measure junior high school students of Indonesia English reading motivation, and face and content validity. Secondly, to assess validity and reliability of modified motivations for reading questionnaire to measure junior high school students' English reading motivation.

\section{METHOD}

Fifty-three items of the questionnaire were adapted from Wang and Guthrie MRQ 2004. This questionnaire was initially processed qualitatively. It means the questionnaire was discussed its face and content validity with validators. It involves four senior lecturers of the English Department of State Islamic Institute of Kerinci who had owned doctoral degree in English. In this case, the motivations for the reading questionnaire were first translated into the Indonesian version. Then validators were asked their suggestion related to the result of the translation. Wang \& Guthrie's motivations for reading the questionnaire are figured out in Table 1 (see Appendix A).

Table 1. Dimensions of Wang \& Guthrie's Motivations for Reading Questionnaire

\begin{tabular}{ccc}
\hline No & Indicators & Sub-Indicators \\
\hline \multirow{2}{*}{1} & Intrinsic Motivation & Reading for Curiosity \\
\cline { 2 - 2 } & & Reading for Involvement \\
\cline { 2 - 2 } & Extrinsic Motivation & Reading for Challenge \\
\cline { 2 - 2 } & & Reading for Recognition \\
\cline { 2 - 2 } & & Reading for Grades \\
\cline { 2 - 2 } & & Reading for Compliance \\
\hline
\end{tabular}


This study used a survey design that used a questionnaire in collecting the data. The respondents were asked to rate their agreement for each statement in the form of a Likert scale ranging from 1-5 by selecting the appropriate statements; strongly disagree (1), disagree (2), Neutral (3), Agree (4), strongly disagree (5). Initially, the online-based questionnaire was distributed to 256 second-grade students of the third grades of SMP N 14 Kota Jambi academic years 2018/2019 voluntarily participating in this study. It was on July 14th, 2020. The questionnaire was written in Indonesia. However, only 83 students returned the questionnaire. The data collected were processed using the statistical package for social science (SPSS version 23) analyses to establish validity and reliability. The corrected items' total correlation was used to examine the validity and reliability of motivations for reading the questionnaire. The items were considered valid when the items had a level of correlation $\geq$ of 0.18 and reliable when Cronbach alpha internal consistency coefficient $\geq 0.50$. The researcher mainly uses the SPSS analyses, which helps them process critical data in simple steps. The researcher only followed the technique of data analyses for a few minutes by analyzing, transforming the collected data to SPSS software.

\section{FINDINGS}

They also evaluated the motivations for reading questionnaires with Indonesian junior high students as English foreign language learners. The process of translation, face, and content validity motivations for reading the questionnaire did not reveal any problematic items for the questionnaire purpose. Notably, four independent validators English and Indonesian, did not significantly differ in translation results between the original and Indonesian versions. The relevancy of the evaluation of the instruments in this study means the formulation of sentences in the affirmative statement that required an answer, the clarity of instruction, formulation of communicative sentences, the appropriateness of language used for the participants. Based on the discussion result of four independent validators, most of the items in each need to be modified to make them understandable. This case is due to the consideration that English is a foreign language for participants of the study. Moreover, English is mainly introduced when the students study at junior high school in Indonesia, different from other Asian countries such as Singapore, Malaysia, Thailand, and the Philippines, introduced to students at Elementary school. Thus, the term of reading must be specified in English text reading for most items of the MRQ dimension.

\section{MRQ Modification Process}

Stewart et al. (2012) viewed that there are types of modification; minor modifications, moderate modifications, substantial modifications. First, minor modifications are modifying the instrument by not changing content or meaning. Second, moderate modifications are meant modifying the meaning of the items in small. The last one is substantial modifications. It is changing the content or meaning of the items, including dropping them in an instrument of the study. The MRQ items for each dimension modification are arranged sequentially as the following:

\section{Reading for Curiosity}

1. I like to read things that are of interest to me (Saya suka membaca topic teks bahasa Inggris yang menarik) 
2. If the teacher discusses something interesting, I might read more about it (Saya akan membaca teks bahasa inggris sampai tuntas seandainy guru mendiskusikan topik yang menarik).

3. I have favorite subjects that I like to read about (Saya suka membaca topic text bahasa inggris favorit saya)

4. I read to learn new information about topics that interest me (Saya membaca teks bahasa Inggris untuk mempelajari informasi baru yang menarik untuk dipelajari).

5. I read about my hobbies to learn more about them (Saya membaca teks bahasa inggris tentang hobi saya untuk saya pelajaris ecara mendalam).

6. I like to read about new things (Saya suka membaca teks bahasa inggris tentang topik yang baru)

7. I enjoy reading books about people in different countries (Saya senang membaca text bahasa inggris tentang tokoh-tokoh terkenal dunia).

All of the Reading for curiosity dimension items were modified. Items number 1, 2, 3, 4, 5 , and 6 are minor modifications. However, there were changes in grammar, not changing the content or meaning of the items. Such as item number 2 suggested by the validators to change the position of conditional sentences at the second clause to make it more accurate and easier to understand the participants. Only item number 7 in moderate modifications. This item has specified the term of people which have general meaning into world-famous figures.

\section{Reading for Involvement}

8. If I am reading about an interesting topic, I sometimes lose track of time (Saya kadangkadang lupa terhadap waktu ketika saya membaca teks bahasa Inggris yang menarik).

9. I read stories about fantasy and make believe (Ketika membaca cerita fiksi dalam bahasa inggris, saya merasa percaya dengan isi cerita).

10. I like mysteries (Saya merasa menikmati ketika membaca cerita horror dalam bahasa Inggris).

11. I make pictures in my mind when I read (Saya membayangkan dalam pikiran saya tentang isi bacaan text bahasa inggris yang saya baca).

12. I feel like I made friends with people in good books (Saya merasa ada di dalam cerita ketika membaca teks bahasa Inggris yang menarik).

13. I like to read a lot of adventure stories (Saya suka membaca teks bahasa inggris tentang pertualangan).

14. I enjoy a long, involved story or fiction book (Saya merasa senang dan ada di dalam cerita ketika membaca cerita fiksi yang panjang dalam bahasa Inggris).

Items number $8,11,13$, and 14 were modified in minor modification. These four items changed little but did not change the content or meaning of the items, such as item number 1 was a slight change in grammar; the position of the conditional sentence into relative pronoun that considered appropriate for junior high school students of Indonesian level. On the contrary, item numbers 9, 10, and 12 are in moderate modification. Item number 9, fantasy, is changed into fiction based on the consideration that junior high school students in Indonesia used to teach through a fiction story. Then item number 10, the mystery, is changed into horror to make it specific.

\section{Reading for Challenge}

15. I like hard, challenging books (Saya suka membaca teks bahasa inggris yang sulit dan menantang). 
16. If the project is interesting, I can read difficult material (Tugas teks bahasa inggris yang menarik membuat saya termotivasi untuk membaca).

17. I like it when the questions in books make me think (Saya suka membaca teks bahasa Inggris yang membuatsayaberpikir tentang isi bacaan).

18. I usually learn difficult things by reading (Saya akan membaca teks bahasa inggris berulang-ulang ketika menemukan istilab dalam bahasa inggris yang sulit saya pahami).

19. If a book is interesting, I don't care how hard it is to read (Saya tidak, perduli betapa pun sulitnya teks bahasa inggris yang saya baca apabila topiknya menarik).

20. I feel I enjoy the contents of the English text when reading interesting and long stories (Saya merasa menikmati isi teks bahasa inggris ketika membaca cerita yang menarik dan panjang).

21. I always try to practice reading English texts so that I can do better in the next reading material (Saya selalu mencoba berlatih membaca teks bahasa Inggris agar dapat melakukan yang lebih baik di materi reading selanjutnya).

There was no changing the meaning and content of all items in reading for the challenge. The validators only suggested arranging the grammar of each item to make it appropriate with junior high students of Indonesia as EFL learners. In other words, all of the reading for challenge items in minor modification. However, two items were added to support 15, 16, 17, 18, 19, exactly items 20 and 21. These two items are considered essential to strengthen existing items of reading for the challenge.

Reading for Recognition

22. I like having the teacher say I read well (Saya senang ketika guru mengatakan bahwa saya mampu memahami teks bahasa Inggris dengan baik)

23. I like having my friends sometimes tell me I am a good reader (Saya senang ketika teman sekelas mengatakan bahwa saya memiliki kemampuan yang bagus dalam memahami isi teks bahasa inggris).

24. I like to get compliments for my reading (Saya senang mendapat pujian dari guru dan teman sekelas terhadap kemampuan saya memahami teks bahasa inggris).

25. I am happy when someone recognizes my reading (Saya senangketikateman di kelas lain memintatanggapansayaterhadaptugasteks reading yang merekakerjakan).

26. I like having my parents often tell me what a good job I am doing in reading (Saya senang ketika orang tua saya memuji hasil pekerjaan saya dalam menjawab soal teks bahasa inggris).

27. I am happy when the teacher asks me to read English texts in front of my classmates (Saya senang ketika guru meminta saya untuk membaca teks bahasa Inggris di depan teman sekelas).

Reading for recognition was also modified in minor modifications like the reading items for the challenge previously. However, there is an additional item in this dimension of reading motivation, exactly item 27. This item was expected to enable to strengthen all of the items of reading for recognition.

Reading for Grades

28. Grades are a good way to see how well you are doing in reading (Nilai merupakan standard untuk mengukur kemampuan siswa dalam membaca teks bahasa inggris). 
29. I look forward to finding out my reading grade (Mendapat nilai membaca teks bahasa inggris yang bagus sangat penting bagi saya).

30. I like to read to improve my grades (Saya yakin bahwa kemampuan membaca dalam bahasa inggris yang baik mempengarubi nilai bidang studi bahasa inggris saya secara keseluruban).

31. I am willing to work hard when reading English texts to get good grades (Saya bersedia bekerja keras ketika membaca teks bahasa inggris untuk mendapat nilai yang bagus).

32. I like my parents to ask me about my reading grade (Saya merasa senang apabila orang tua saya menanyakan nilai saya dalam membaca teks bahasa inggris).

There were no changes of content or meaning in Items number 28 and 30. On the contrary, item number 29 changed the meaning in miniature to make them appropriate with the target participants observed. The validators also suggested adding one more item for item number 31 (between item 30 and 32) to strengthen the participants' comprehension.

\section{Reading for Social}

33. I like to visit the library often with my family (Saya senang mengunjungi pustaka bersama temanteman dan membaca buku bahasa inggris)

34. I often like to read to my brother or my sister (Saya senang membantu adik saya menyelesaikan tugas menjawab pertanyaan teks bahasa inggris mereka di rumah).

35. My friends and I like to trade things to read (Saya senang berbagi dengan teman sekelas tentang topic teks bahasa Inggris yang saya baca ketika belajar dalam kelas).

36. I sometimes read to my parents (Saya suka menceritakan kepada orang tua saya tentang isi teks bahasa inggris yang saya baca).

37. I like to talk to my friends about what I am reading (Saya suka memberitabukan isi teks bahasa inggris yang saya baca ke teman sekelas).

38. I like to help my friends with their schoolwork in reading (Saya senang membantu temanteman sekelas dalam memahami teks bahasa Inggris yang kami baca).

39. I like to tell my family about what I am reading (Saya senang ketika teman sekelas mendiskusikan dengan saya tentang teks bahasa inggris yang merekabaca).

40. My classmates and I enjoy sharing knowledge from the English texts that we read (Teman sekelas dan saya senang berbagi pengetahuan dari teks bahasa inggris yang kami baca).

Most items of reading for social modified is in minor modification, except item 39 in substantial modifications. The items were not changed in content or meaning because they were appropriate with the target participants. Only the grammar arrangement was changed to make it suitable with participants' grammar level. In this MRQ dimension, there was one more additional item, especially item number 40 , suggested by validators.

\section{Reading for Competition}

41. I try to get more answers right than my friends (Saya mencoba memabami isi teks bahasa inggris lebih maksimal dari pada teman sekelas saya).

42. I like being the best at reading (Saya berusaha untuk menjawab pertanyaan text bahasa inggris dengan benar dari pada teman-teman sekelas saya).

43. I like to finish my reading before other students (Saya senang menjadi siswa yang terbaik di kelas dalam materi reading). 
44. I like being the only one who knows an answer in something we read (Saya suka menyelesaikan tugas text bahasa Inggris terlebih dabulu sebelum siswa yang lain selesai).

45. It is important for me to see my name on a list of good readers (Saya sukamenjadisatusatunyasiswa yang tahujawabandaripertanyaanteksbahasainggris yang kami baca).

46. I try hard to read English text when my classmates have better abilities than me (Saya berusaha semaksimal mungkin membaca text bahasa inggris ketika teman sekelas saya memiliki kemampuan yang lebihbagusdarisaya).

47. I am willing to work hard to read better than my friends (Saya bersedia bekerja keras membaca teks bahasa inggris untuk menjadi yang terbaik).

Four validators suggested a minor modification for all items of reading for the competition provided. However, one additional item is considered essential to strengthen reading for the competition dimension. It is item number 46.

\section{Reading for Compliance}

48. I always do my reading work exactly as the teacher wants it (Saya selalu mengerjakan tugas teks bahasa Inggris yang diberikan oleh guru).

49. Finishing every reading assignment is very important to me (Menyelesaikan setiap tugas teks bahasa inggris yang diberikan oleh guru penting bagi saya).

50. I read because I have to (Saya membaca teks bahasa inggris untuk memahami isi bacaan).

51. I always try to finish my reading on time (Saya selalu berusaha menyelesaikan tugas membaca text bahasa Inggris tepat waktu).

52. When the teacher discusses challenging English text topics, I feel responsible for solving them (Ketika guru membahas topic teks bahasa inggris yang menantang, saya merasa bertanggung jawab untuk menyelesaikannya).

53. Reading interesting English text topics makes me motivated to understand the content (Membaca topic teks bahasa Inggris yang menarik membuat saya termotivasi untuk memahami isi teks).

Based on the modification result of reading for compliance, there was mostly no changing of content or meaning in all of the items provided. It means that they were modified in minor modifications. However, validators suggested adding two more items to strengthen provided reading compliance items. Those two items are items number 52 and 53.

\section{Validity and Reliability Analysis}

Validity and reliability assessments of reading motivation were administered to research respondents after the modification process. Assessing the validity and reliability of the questionnaire is the way to help the researchers to know the ambiguities present in each questionnaire item (Dawson, 2002). It attempts to assess the comprehension of questionnaire items and the time required to rate the items' statements. In this case, the respondents were asked to rate 53 statement items of motivation of reading questionnaire in the form of Likert scale, then analyzed using Corrected item-total Correlation analysis of SPSS 23.

The items were considered valid when they had a level of correlation greater than 0.18 and reliable with a consistency coefficient greater than 0.50 . The results of the SPSS analysis of the 53 motivations for reading questionnaires returned by the 83 respondents were higher than 0.18. All 53 items were considerably valid based on the level of correlation in statistical analysis of 
SPSS 23, as mentioned previously. The Corrected item-total Correlation analysis also showed the reliability of the 53 motivation for reading questionnaire items internal consistency coefficient was 0.98 greater than 0.50 (see Appendix B). It indicated that the questionnaire had a robust reliability coefficient. Based on the SPSS statistical analysis results, all of the 53 motivation of reading questionnaire items were appropriate for measuring the reading motivation of Junior high school students in Indonesia.

\section{DISCUSSION}

Questionnaires as a screening tool for measuring reading motivation had already been frequently used in English education research. By increasing the research in motivations for reading English as a foreign language, modifying the existing questionnaire of motivations for reading becomes essential because of the need for data on the students' reading motivation in English as a foreign language. Therefore, the existing questionnaires need to be modified into targeted participants' language. The modification of the motivation of questionnaire items is to make them appropriate with the target participants of the study. Stewart et al. (2012) viewed some reasons of modification of the study instrument "a concept or dimension may be missing from a measure, the meaning of the concepts or items may differ, items/phrases may not be interpreted as intended, the process of responding to the questions is complex or difficult, and the study context or mode of administration may differ from the original."

The 53 items of motivation for the reading questionnaire were initially translated into Indonesia by four linguists to maintain the quality of translation and ensure back translation. They were asked to validate the researcher's translation result of motivations for reading the questionnaire. This technique was used to avoid bias and minimize the loss of original motivations for reading like a foreign language questionnaire and then, followed by validating the face and content of the questionnaire items by the four linguists for evaluating the relevancy of the questionnaire with Indonesian junior high students as the participants of the study. The relevancy of the evaluation of the instruments in this study means the formulation of sentences in the affirmative statement that required an answer, the clarity of instruction, formulation of communicative sentences, the appropriateness of language used for the participants. The translation of motivations for reading questionnaire items into Indonesia made them more understandable for the study respondents.

The following data collection steps assess the validity and reliability of motivations for reading questionnaires (MRQ). Validity and reliability assessment is used to help the researchers know the ambiguities present in each questionnaire item. It needs to be conducted to test questionnaire items' comprehension and the time required to answer them. The voluntary students were asked to rate their statements on a Likert scale by selecting the appropriate statement.

The study finding is similar to (Aggio, Fairclough, Knowles, \& Graves, 2016; Anshory, Wahono, Kalim, \& Rasyid, 2018; Caruso et al., 2019; Malloy, Marinak, Gambrell, \& Mazzoni, 2013; Taber, 2018). Aggio Fairclough, Knowles, and Graves (2016) argued that a modification physical activity questionnaire was required after it was assessed to different students and before it was administered for adolescents as the targeted research samples. Moreover, Anshory Wahono, Kalim, and Rasyid (2018), who assessed the Copcord questionnaire to 100 respondents for measuring diagnosis of rheumatic diseases, concluded that the modified Copcord 
questionnaire could be used as the screening tool of joint pain and musculoskeletal diseases compared to examination by rheumatologists.

Caruso et al. (2019), who developed and modified Research Utilization Questionnaire by constructing content and face validity and also assessed the validity and reliability, found that Research Utilization Questionnaire is a valid instrument for measuring research utilization and attitude. Malloy, Marinak, Gambrell, and Mazzoni (2013) stated that a reliable research instrument is beneficial for teachers in measuring the students' reading motivation as the component of a good research instrument. Similarly, Indrayadi (2021) assessed his motivation reading questionnaires to other students to assess the validity and reliability of his research instrument to be used as a screening tool in measuring the Indonesian EFL students.

\section{CONCLUSION}

The finding showed that the modification, development, validity, and reliability of motivations for reading questionnaires to measure the EFL students' reading motivation need to be done for adapted motivations for reading questionnaires. For this study, the modification and development of motivations for reading like a foreign language questionnaire found all 53 items were valid because the correlation level of the items was more significant than 0.18 and highly reliable, as demonstrated by Cronbach's Alpha coefficient 0.98. It indicated that Motivations for reading questionnaire modification was considered appropriate in measuring the EFL students' reading motivation. The implication can be drawn from the finding of this study that it would help the other researchers modify and assess the validity and reliability of the research instrument. Although this study can help other researchers modify and assess the validity and reliability of the motivation reading questionnaire for measuring the reading motivation of Indonesian students, it is not representative of all Indonesian students, and maybe there are many different characteristics of the students. The research related to modifying and assessing the motivation reading questionnaire needs to be conducted for junior high school students in another province in Indonesia.

\section{REFERENCES}

Aggio, D., Fairclough, S., Knowles, Z., \& Graves, L. (2016). Validity and reliability of a modified English version of the physical activity questionnaire for adolescents. Archives of Public Health, 74(3), 2-9.

Alhamdu. (2015). Interest and Reading Motivation. PSIKIS-Jurnal Psikologi Islami, 1(1), 1-10. Retrieved from https://www.researchgate.net/publication/323576174.

Anshory, M., Wahono, C. S., Kalim, H., \& Rasyid, H. A. (2018). Validation of Modified COPCORD Questionnaire Indonesian Version as Screening Tool for Joint Pain and Musculoskeletal Diseases. Indonesian Journal of Rheumatology 10(1), 24-30.

Caruso, R., Pittella, F., Grugnetti, A. M., Ausili, D., Pastore, U., Stievano, A., Dellafiore, F., \& Arrigoni, C. (2019). Modified Research Utilization Questionnaire: Development and Validation Study among Italian Nurses. Asian Nursing Research, 13, 61-68.

Dawson, C. (2002). Practical Research Methods, New Delhi, UBS Publishers’ Distributors. 
Guthrie, J. T., Coddington, C.S., \& Wigfield, A. (2009). Profiles of Reading Motivation among African American and Caucasian students. Journal of Literacy Research, 41(1), 317-353.

Indrayadi, T. (2021). Indonesian EFL Learners' Reading Motivation. Indonesian Journal of English Language Teaching and Applied Linguistics, 5(2), 335-346.

Jones, B. D. (2009). Motivating Students to Engage in Learning: The MUSIC Model of Academic Motivation. International Journal of Teaching and Learning in Higher Education. 21(2), 272-285. Retrieved from http://www.isetl.org/ijtlhe/

Malloy, J. A., Marinak, B. A., Gambrell., \& Mazzoni, S. A. (2013). Assessing Motivation to Read: The Motivation to Read Profile-Revised. The Reading Teacher. 67(4), 273-282.

Stewart, A. L., Thrasher, A. D., Goldberg, J., Shea, J. A. (2012). A Framework for Understanding Modifications to Measures for Diverse Populations. J Aging Health. 24(6), 992-1017.

Taber, K. S. (2018). The Use of Cronbach's Alpha When Developing and Reporting Research Instruments in Science Education. Res Sci Educ, 48, 1273-1296

Wang, J. H., \& Guthrie, J. T. (2004). Modeling the effects of intrinsic motivation, extrinsic motivation, amount of reading, and past reading achievement on text comprehension between U.S. and Chinese students. Reading Research Quarterly. 39 (2), 162-186. 


\section{Appendix A}

\begin{tabular}{|c|c|}
\hline & Wang and Guthrie's MRQ \\
\hline Sub-Indicators & Items \\
\hline Reading for & 1. I like to read things that are of interest to me. \\
\hline Curiosity & $\begin{array}{l}\text { 2. If the teacher discusses something interesting, I might read more about } \\
\text { it. }\end{array}$ \\
\hline & 3. I have favorite subjects that I like to read about. \\
\hline & $\begin{array}{l}\text { 4. I read to learn new information about topics that interest me. } \\
\text {. }\end{array}$ \\
\hline & 5. I read about my hobbies to learn more about them. \\
\hline & 6. I like to read about new things. \\
\hline & 7. I enjoy reading books about people in different countries. \\
\hline Reading for & 8. If I am reading about an exciting topic, I sometimes lose track of time. \\
\hline Involvement & 9. I read stories about fantasy and make-believe. \\
\hline & 10. I like mysteries. \\
\hline & 11. I make pictures in my mind when I read. \\
\hline & 12. I feel like I made friends with people in good books. \\
\hline & 13. I like to read many adventure stories. \\
\hline & 14. I enjoy a long, involved story or fiction book. \\
\hline Reading for & 15. I like hard, challenging books. \\
\hline & 16. If the project is interesting, I can read complex material. \\
\hline & 17. I like it when the questions in books make me think. \\
\hline & 18. I usually learn difficult things by reading. \\
\hline & 19. If a book is interesting, I do not care how hard it is to read. \\
\hline Reading for & 20. I like having the teacher say I read well. \\
\hline Recognition & 21. I like having my friends sometimes tell me I am a good reader. \\
\hline & 22. I like to get compliments on my reading. \\
\hline & 23. I am happy when someone recognizes my reading. \\
\hline & $\begin{array}{l}\text { 24. I like having my parents often tell me what a good job I am doing in } \\
\text { reading. }\end{array}$ \\
\hline Reading for & 25. Grades are an excellent way to see how well you are doing in reading. \\
\hline Grades & 26. I look forward to finding out my reading grade. \\
\hline & 27. I like to read to improve my grades. \\
\hline & 28. I like my parents to ask me about my reading grade. \\
\hline Reading for & 29. I like to visit the library often with my family. \\
\hline Social & 30. I often like to read to my brother or my sister. \\
\hline & 31. My friends and I like to trade things to read. \\
\hline & 32. I sometimes read to my parents. \\
\hline & 33. I like to talk to my friends about what I am reading. \\
\hline & 34. I like to help my friends with their schoolwork in reading. \\
\hline & 35. I like to tell my family about what I am reading. \\
\hline Reading for & 36. I try to get more answers suitable than my friends. \\
\hline Competition & 37. I like being the best at reading. \\
\hline & 38. I like to finish my reading before other students. \\
\hline & 39. I like being the only one who knows an answer to something we read. \\
\hline & 40. I need to see my name on a list of good readers. \\
\hline & 41. I am willing to work hard to read better than my friends. \\
\hline Reading for & 42. I always do my reading work exactly as the teacher wants it. \\
\hline Compliance & 43. Finishing every reading assignment is very important to me. \\
\hline & 44. I read it because I have to. \\
\hline & 45. I always try to finish my reading on time. \\
\hline
\end{tabular}




\section{Appendix B}

Item-Total Statistics

\begin{tabular}{|c|c|c|c|c|}
\hline & $\begin{array}{l}\text { Scale Mean if } \\
\text { Item Deleted }\end{array}$ & $\begin{array}{l}\text { Scale Variance } \\
\text { if Item Deleted }\end{array}$ & $\begin{array}{l}\text { Corrected Item- } \\
\text { Total Correlation }\end{array}$ & $\begin{array}{l}\text { Cronbach's Alpha } \\
\text { if Item Deleted }\end{array}$ \\
\hline VAR00001 & 182,1446 & 1152,028 & 632 & ,978 \\
\hline VAR00002 & 182,0241 & 1145,536 &, 576 & 978 \\
\hline VAR00003 & 182,0964 & 1142,942 & ,722 & 978 \\
\hline VAR00004 & 181,9157 & 1146,810 & ,675 & ,978 \\
\hline VAR00005 & 181,8434 & 1143,817 & ,644 & ,978 \\
\hline VAR00006 & 182,0723 & 1153,263 & ,572 & ,978 \\
\hline VAR00007 & 182,1446 & 1148,979 &, 575 & ,978 \\
\hline VAR00008 & 182,6145 & 1163,386 & ,361 & 979 \\
\hline VAR00009 & 182,6386 & 1158,160 & ,444 & 979 \\
\hline VAR00010 & 182,2771 & 1144,032 & ,603 & ,978 \\
\hline VAR00011 & 182,2048 & 1149,823 & ,582 & 978 \\
\hline VAR00012 & 182,1687 & 1149,898 &, 536 & 979 \\
\hline VAR00013 & 182,2289 & 1145,227 & 622 & 978 \\
\hline VAR00014 & 182,4940 & 1159,692 & ,402 & 979 \\
\hline VAR00015 & 182,6747 & 1154,759 & ,461 & 979 \\
\hline VAR00016 & 182,0723 & 1141,775 & 696 & 978 \\
\hline VAR00017 & 182,3614 & 1139,160 & ,672 & ,978 \\
\hline VAR00018 & 182,1325 & 1150,897 & ,535 & 979 \\
\hline VAR00019 & 182,3976 & 1152,364 &, 555 & ,978 \\
\hline VAR00020 & 182,2892 & 1147,403 & 655 & ,978 \\
\hline VAR00021 & 181,9036 & 1132,722 & ,758 & ,978 \\
\hline VAR00022 & 181,8675 & 1118,019 & 820 & 978 \\
\hline VAR00023 & 181,8795 & 1125,424 & 805 & ,978 \\
\hline VAR00024 & 181,9639 & 1129,523 & ,752 & ,978 \\
\hline VAR00025 & 182,1446 & 1139,711 & 698 & ,978 \\
\hline VAR00026 & 181,7470 & 1126,118 &, 751 & ,978 \\
\hline VAR00027 & 182,3855 & 1145,996 & ,623 & ,978 \\
\hline VAR00028 & 182,0602 & 1138,374 & ,754 & ,978 \\
\hline VAR00029 & 181,9036 & 1130,649 &, 744 & ,978 \\
\hline VAR00030 & 181,9398 & 1143,130 & ,612 & 978 \\
\hline VAR00031 & 181,8916 & 1129,781 & ,786 & ,978 \\
\hline VAR00032 & 182,0241 & 1137,146 & ,704 & ,978 \\
\hline VAR00033 & 182,3133 & 1142,608 & 697 & ,978 \\
\hline VAR00034 & 182,2771 & 1139,910 & ,666 & ,978 \\
\hline VAR00035 & 182,1084 & 1142,683 & ,702 & 978 \\
\hline VAR00036 & 182,2289 & 1139,545 & ,685 & 978 \\
\hline VAR00037 & 182,4578 & 1148,202 &, 584 & ,978 \\
\hline VAR00038 & 182,0964 & 1142,308 & ,709 & ,978 \\
\hline VAR00039 & 182,0361 & 1143,133 &, 750 & 978 \\
\hline
\end{tabular}




\begin{tabular}{|l|l|l|l|r|} 
VAR00040 & 182,0361 & 1141,352 &, 729 &, 978 \\
VAR00041 & 182,0241 & 1144,756 &, 640 &, 978 \\
VAR00042 & 181,9518 & 1135,729 &, 776 &, 978 \\
VAR00043 & 182,1205 & 1132,937 &, 736 &, 978 \\
VAR00044 & 182,2410 & 1132,575 &, 785 &, 978 \\
VAR00045 & 182,3735 & 1144,749 &, 566 &, 978 \\
VAR00046 & 181,9398 & 1133,813 &, 809 &, 978 \\
VAR00047 & 182,0000 & 1131,927 &, 819 &, 978 \\
VAR00048 & 181,9036 & 1131,503 &, 758 &, 978 \\
VAR00049 & 181,7590 & 1130,210 &, 802 &, 978 \\
VAR00050 & 182,0120 & 1139,573 &, 750 &, 978 \\
VAR00051 & 182,0000 & 1128,829 &, 813 &, 978 \\
VAR00052 & 182,2048 & 1140,872 &, 724 &, 978 \\
VAR00053 & 181,9880 & 1126,841 &, 815 & \\
\hline
\end{tabular}

